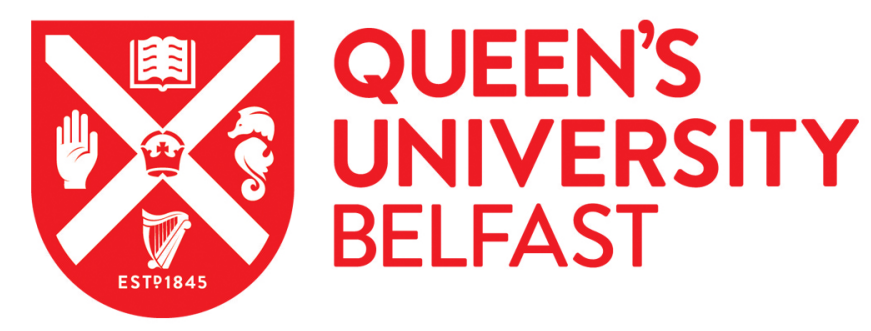

\title{
Landscape, season and identity in Ghost Story for Christmas
}

Johnston, D. (2018). Landscape, season and identity in Ghost Story for Christmas. Journal of Popular Television, 6(1), 105-118. https://doi.org/10.1386/jptv.6.1.105_1

Published in:

Journal of Popular Television

Document Version:

Peer reviewed version

Queen's University Belfast - Research Portal:

Link to publication record in Queen's University Belfast Research Portal

Publisher rights

(C) 2017 Intellect.

This work is made available online in accordance with the publisher's policies. Please refer to any applicable terms of use of the publisher.

\section{General rights}

Copyright for the publications made accessible via the Queen's University Belfast Research Portal is retained by the author(s) and / or other copyright owners and it is a condition of accessing these publications that users recognise and abide by the legal requirements associated with these rights.

Take down policy

The Research Portal is Queen's institutional repository that provides access to Queen's research output. Every effort has been made to ensure that content in the Research Portal does not infringe any person's rights, or applicable UK laws. If you discover content in the Research Portal that you believe breaches copyright or violates any law, please contact openaccess@qub.ac.uk. 


\title{
Landscape, season and identity in the Ghost Story for Christmas
}

Derek Johnston, Queen's University

\begin{abstract}
The BBC Ghost Story for Christmas (1971-1978, 2005-2006, 2015) used the English landscape in which it was set to engage with a series of associations of national identity and to enhance the feeling of isolation experienced by the protagonists. This was further enhanced by the representation of the seasons within these productions, which typically emphasized an autumnal landscape. This suggested a liminal period, neither summer nor winter, and one that presented environments of rustling vegetation and trees through which supernatural figures may be glimpsed or heard approaching. While the Ghost Story for Christmas is by no means alone in using these environments and associations, the importance of their presentation of landscape to their identity has been recognized by reviewers, with the presentation itself emphasizing the narratives' disruption of any sense of naturalness and certainty to narratives of human, English history and thus identity.
\end{abstract}

\section{Keywords}

\section{Christmas}

\section{$\underline{\text { Englishness }}$}

ghost story

$\underline{\text { identity }}$ 
isolation

landscape

Enosh

seasonality

Describing the characteristics of the typical Ghost Story for Christmas (1971-1978, 2005-

2006, 2015) in The Guardian, Sarah Dempster included 'stunning, panoramic shots of a specific area of the British landscape', alongside elements such as 'determined lack of celebrity pizzazz', 'tweed' and 'a single moment of heart-stopping, corner-of-the-eye horror' (2005: 6). This description of the essential attributes of the programmes, as Dempster perceived them, clearly places the landscape at the centre of these productions. Not only that, but this is a specifically British landscape and one that is presented expansively. This article explores the significance of this representation of landscape within these productions, demonstrating that they draw upon embedded cultural conceptions of the landscape and its meaning, in addition to utilizing the natural environment as part of their development of a sense of unease appropriate to their horror narratives. This is true of many horror productions, but more specific to the Ghost Story for Christmas is the way that this unease is tied up with notions of national identity, and particularly with questioning any sense of stability of identity or connection between land and nation. These connections are, in part, emphasized by the significance of the season to the productions, expressed most clearly by their being intended for a particular time of year, Christmas, but also through the representation of the seasons within the productions.

The Ghost Story for Christmas was an annual BBC drama strand, presenting one new episode each year, which ran throughout the 1970s and which saw several attempts at revival 
in the 2000s. Most of the episodes were adaptations of ghost stories by Edwardian academic and ghost story writer M. R. James, although the series also presented one Dickens adaptation and two original, contemporary (to the 1970s) narratives. The productions explored are those that were considered by those producing them to be part of a series commonly referred to as the Ghost Story for Christmas series, and are as follows: The Stalls of Barchester (1971), A Warning to the Curious (1972), Lost Hearts (1973), The Treasure of Abbot Thomas (1974), The Ash Tree (1975), The Signalman (1976), Stigma (1977), The Ice House (1978), A View From a Hill (2005), Number 13 (2006) and The Tractate Middoth (2013). The 1970s' productions, with the exception of The Ice House, were all directed by Lawrence Gordon Clark, who created the series, and these were all seen as being connected despite changes of personnel and even department, as demonstrated not only by comments from Clark in sources such as interviews on the DVDs of the productions but also by the BBC Audience Research Reports, which consider them under this group title. A View From a Hill was produced by Pier Wilkie, who directed Number 13, and considered to be a revival of the 1970s' tradition. Similarly, Mark Gatiss' The Tractate Middoth was intended as a continuation/revival of the Ghost Story for Christmas and included that title in its opening credits.

This means that the Ghost Story for Christmas strand originated with a strong authorial figure, Clark, who acted as adaptor, producer and director for The Stalls of Barchester and A Warning to the Curious, and continued as director for all but the last of the initial 1970s' run. These positions, and the relatively free reign that Clark was given (within budget), meant that he was able to establish a strong visual style for the productions, one that the later programme makers consciously sought to emulate. Each presented a view of the natural world that displayed it as both beautiful and unsettling, as a setting for horror rather than horrific in itself, and in particular as being set apart from human activity and the stories playing out within the landscape. In other words, this is not landscape as echo of human 
emotions or human actions, or commentary on the narrative; this is landscape as an environment in which a horror narrative plays out, but that is completely unconcerned with human activity, while being given great visual prominence within the programmes. It is this lack of concern that emphasizes that landscape and the natural world should not and cannot really be thought of in human terms, which is a characteristic and significant part of the unsettling nature of these programmes.

\section{The landscapes of the Ghost Story for Christmas}

The Ghost Story for Christmas narratives are primarily period pieces, and so their rural settings are partly of benefit to the production in that they do not require so much in the way of finding specifically period-appropriate settings. That said, the human environment of the narrative is often one that encompasses a number of buildings and locations, such as the cathedral close and cathedral of The Stalls of Barchester; the seaside town and associated church, farm and railway station in A Warning to the Curious; the inn, cathedral archive and cathedral surroundings in Number 13; and so on. Nevertheless, these places of human activity are typically depicted as rural, surrounded by the countryside and reached only by train, bicycle or, in the case of Stigma, car. Indeed, the typical opening shot of these productions is of a misty or an out-of-focus landscape, with the protagonist arriving into the landscape either in that or in subsequent shots. While this is a common way of introducing the setting of a drama and its lead protagonist, these productions, like many rural horrors, take their time in establishing the setting, producing a sense of expectation while the audience waits to be introduced to human activity and character. This is potentially accompanied by a sense of unease as the viewer searches the landscape depicted for the individual that they know they are expected to engage with and follow through the drama. This suggests that the landscape is 
significant to these dramas, at least in as much as that it emphasizes the isolation of the characters, an aspect that is central to the stories of M. R. James from which so many of these productions are adapted. Considering that James himself was known to be a very sociable man, this sense of isolation is clearly a key aspect of his ghost stories, suggesting one of his own underlying fears as a source for their horrors.

The locations for these narratives are typically liminal places, on the borderlands between the everyday and the wild and ancient. The central characters are typically temporary incomers, those passing through rather than those rooted in the soil. Their environments are thus already strange to them, and they see them and the habits of their inhabitants as something unusual, something other. This is compounded by the frequent positioning of the visitors as having an academic interest, one that is drawn from the study of texts and histories, but whose practical engagement with the past really only takes place with their actions that lead them to be haunted.

Terry W. Thompson has argued that James' stories themselves 'frequently make use of man-modified landscapes to append meaning to his stories, to layer, enrich and deepen their import' (2004: 339), representing the land as 'conquered and docile, bludgeoned into submission by the mighty English broadaxe and the muscular backs of the yeomanry until there is nothing left but an insignificant "fringe of woods" surrounding the clear-cut landscape' (2004: 340). This is a clear example of the liminal borderlands seen throughout the television Ghost Story for Christmas, and yet, of course, the protagonist of both James' tales and the television dramas is often drawn away from the open, cleared land and into the woodland. This is where the 
primordial powers - long dormant beneath the surface façade of order and control - .

Formatted: Indent: First line: $0 \mathrm{~cm}$ rise up to destroy the prideful English squires who had so abused the land, had sought to subdue and dominate and reconfigure it to their own narrow ends. (2004: 340)

As will be discussed later, this article takes issue with this representation of the land as an

Formatted: Indent: First line: $0 \mathrm{~cm}$ active participant in the horrors, but the sense that these wooded borderlands represent a land older than the constructions of human national identity is key.

While the importance of trees in relation to the supernatural is perhaps signalled most clearly in The Ash Tree, woodland is a feature of the landscape in all of the adaptations, with the exception of The Signalman, which is set almost entirely in the claustrophobic confines of a railway cutting and the signalman's hut set within it. Woodland may provide the source of the supernaturally empowered wood from which The Stalls of Barchester are carved, or serve to separate out human settlements and habitations from each other, as with Number 13.

Alternatively, the woodland may itself be a place of haunting; it is where Stephen encounters the ghost children in Lost Hearts, and where the protagonists of both A Warning to the Curious and A View From a Hill are pursued by figures perceived mainly at the corner of the eye. James himself described the particular characteristics of woodland in relation to a sense of being observed in 'A Vignette', writing:

To be sure, it is difficult, in anything like a grove, to be quite certain that nobody is Formatted: Indent: First line: $0 \mathrm{~cm}$ making a screen out of a tree trunk and keeping it between you and him as he moves round it and you walk on. (2006: 207) 
This is particularly captured in the adaption of A View From a Hill, in which Fanshawe's Formatted: Indent: First line: $0 \mathrm{~cm}$ persecution in the woodland is handled entirely through suggestion, with the camera taking the positions of unseen onlookers watching him through foliage, with the actor (Mark Letheren) glancing constantly around at suggested movement, even with the camera rushing towards his turned back, and a cut to Fanshawe grabbing at his neck and spinning around to see no-one behind him. While the pursuit in A Warning to the Curious is undertaken by a definite figure, Ager's ghost is typically part-concealed by the trees and bushes, making it seem more a part of the woodland. This is particularly clear in the scene where Paxton returns the cause of the haunting, the protective Crown of Anglia that he has unearthed, to its burial place; watching over him, Dr Black casts his light across the surrounding trees, revealing pale trunks standing in pitch darkness, and passing over without noticing the figure of Ager standing by one of the trees, watching. 


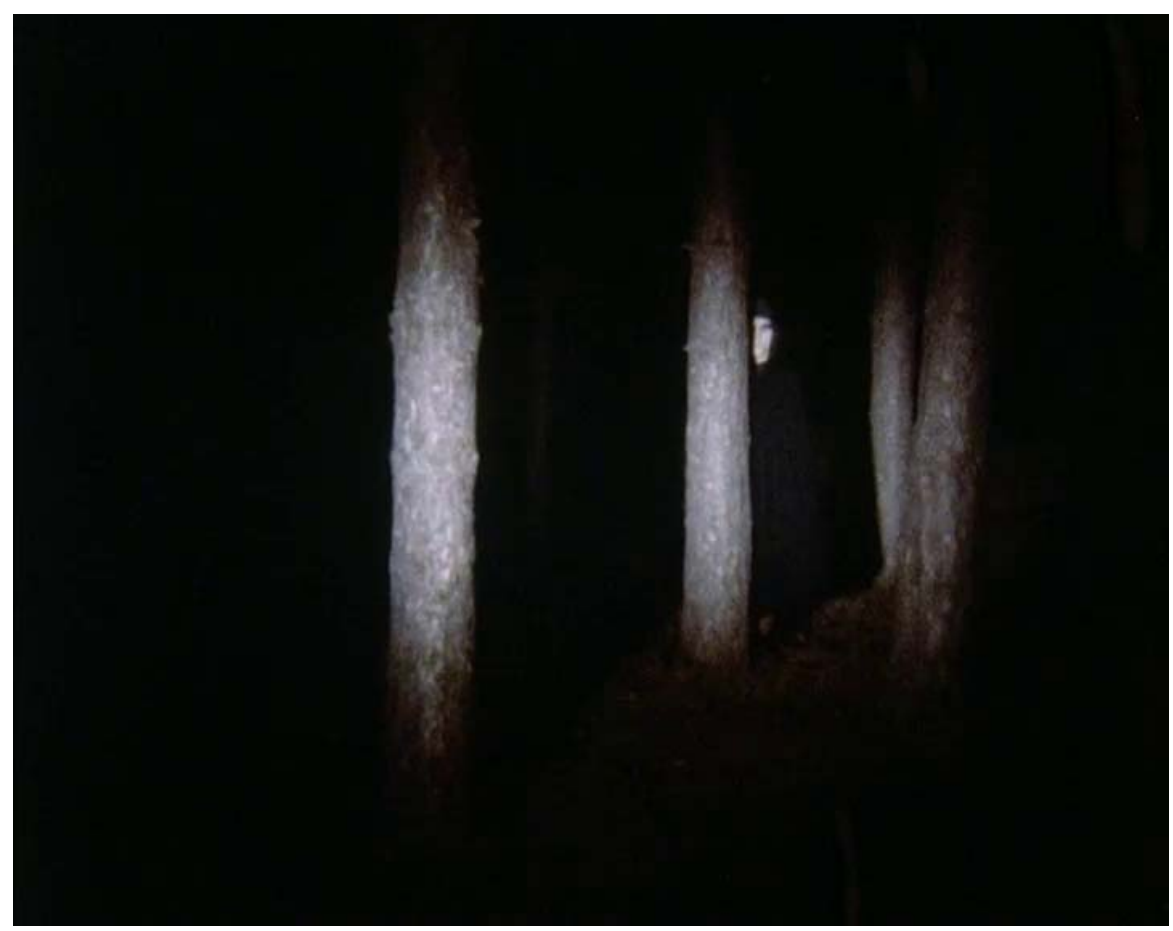

Figure 1: Ager as one with the trees: A Warning to the Curious.

The horror of the woodlands relies not simply on the immediate characteristics of the Formatted: Indent: First line: $1.27 \mathrm{~cm}$ woodland that might encourage caution, such as impeded lines of sight and hard-to-interpret rustling of leaves; it also engages with cultural associations with woodlands as places of myth, wonder and horror. As Macfarlane claims, while:

The deepwood is vanished in these islands - much, indeed, had vanished before history began - we are still haunted by the idea of it. The deepwood flourishes in our architecture, art and above all in our literature. Unnumbered quests and voyages have taken place through and over the deepwood, and fairy tales and dream-plays have been staged in its glades and copses. Woods have always been a place of in- 
betweenness, somewhere one might slip from one world to another, or one time to a

former. (2008: 98)

Similarly, Richard Hayman argues that:

One of the key processes in human history was the creation of a landscape by the introduction of farming and the building of villages. This gave an altered perspective as to the nature of wild places. If the gods do not inhabit the everyday world then they must be sought beyond its boundaries. (2003: 8)

The movement from bright daylight to the shade of the forest, or the change in the atmosphere as night falls, can be understood as limiting the sights that connect the individual to the comforting human landscape. This 'wilding quality of darkness' removes human certainty to return the feeling of the wilderness to a location, bringing back the sense of the place as somewhere outside of human control (Macfarlane 2008: 196). The characters that appear in the Ghost Story for Christmas episodes are those who have gone beyond the boundaries of the everyday and find themselves within a liminal landscape, one in which the rules of the everyday do not hold and where they encounter images of England that are true, yet unreal.

Certainly, there is horror in the woodland of the television Ghost Story for Christmas, particularly in A Warning to the Curious, The Ash Tree, A View From a Hill and The Tractate Middoth. Yet the horror also occurs in the open, in fields and pathways and on beaches, and in rooms in hotels and houses and libraries. When it does appear indoors it is usually with a 
sense that the horror is something that has come into the domestic space from outside, such as Ager's ghost appearing in Paxton's hotel room in A Warning to the Curious when it has mostly been associated with the wood-shrouded mound that concealed the last Crown of Anglia before Paxton dug it up, or the horrifying spider-babies that gain access to Sir Matthew's room via the branches of the titular Ash Tree. This breaching of boundaries and disruption of the normal is typical of the horror genre, but what is informative about these breaches is which boundaries are breached and what is disrupted. In these cases, it is domesticity and the safety of human-constructed buildings that is disrupted by the wild outside.

Glen Creeber's description of the typical characteristics of a 'Nordic Noir' drama is very similar to those that Dempster recognized in the Ghost Story for Christmas: 'a rather slow and understated pace, the dialogue often sparse, monosyllabic and the light frequently muted. While there is clearly action [...] its drama also allows for long moments of stillness and reflection' (quoted in Roberts 2016: 371). Roberts argues that this means that 'the setting, in other words, is "given space" to expressively compliment the performative action of the human characters in the drama that unfolds. Landscape, in short, is afforded the role of "character"' (2016: 371). That said, the landscape or nature itself is not antagonistic in these programmes, with the arguable exception of The Ice House, where the horror is associated with a peculiar vine that grows on the ice house of the title. While each drama may include scenes of horror that take place within the landscape, nature remains a setting rather than an active antagonist. This is most noticeable in the way that the scenes in nature are usually accompanied by birdsong, no matter what the events taking place within that setting. There is no sudden unsettling silence for scenes of pursuit or assault. Nature operates at too different a scale to humans to care about what happens to them; nature is sublimely, awe-fully unconcerned with these little individuals. Thompson argues that 
when finally compared with the vast natural energies it claims to dominate and rule,

Formatted: Indent: First line: $0 \mathrm{~cm}$ however, that human power is shown - by the end of James's wonderfully chilling tales - to be weak, fallible, inferior, and temporal, as insignificant as a single shriek in a howling whirlwind. (2004: 352)

But it is not just the irrelevance of individual humans in the grand scheme of things that is signalled by this indifference. This lack of engagement between individual and environment not only disrupts genre expectations - that the impending horror is signalled by nature going quiet, registering the 'unnatural' intrusion - but also imbedded cultural associations between the landscape, character and national identity.

\section{Landscape and identity}

Connections between landscape and identity are numerous, deeply buried and barely acknowledged, particularly in an English context, such as that of The Ghost Story for Christmas. David Lowenthal has claimed that

one icon of heritage has a distinctly English cast. That is the landscape. Nowhere else is landscape so freighted as a legacy. Nowhere else does the very term suggest not simply scenery and genres de vie, but quintessential national virtues. (1991: 213) 
As noted earlier, the landscapes of The Ghost Story for Christmas are specifically English, although commentators may perform the common conflation of Englishness and wider Britishness.

As Billig argues, 'a nation is more than an imagined community of people, for a place - a homeland - also has to be imagined' (1995: 74). Landscape is intimately connected to notions of nation as the nation is taken to be a combination of physical and social geography. It is the human connected to the physical location, often linking the characteristics associated with the geographical qualities of the nation, or the region, with the qualities that make up the particular national, or regional, identity. However, there are also the more 'mystical' associations that develop between particular landscapes and national identities.

In the case of England, one of the key landscape types is woodland, which is significant to a number of the adaptations considered here. The initial association of woodland with Englishness was practical as English trees provided the wood to build the fleet that protected England from invasion and spread its power around the world. This practical association grew to become more mystical, through legends of woodland outlaws and tales of the greenwood as refuge, or through "the theories of Richard Payne Knight, for whom "native woods" were "creation's boast and pride"' (Hayman 2003: 95). The type of woodland became important; Richard Hayman records that 'Ruskin identified a particularly English form of woodland, with "sunny glade, and various foliage, and dewy sward" quite distinct from the black forests of other nations' (2003: 95). In this way, not only was woodland made a central part of the idea of Englishness, but it was emphasized that there was a very specific expression of the natural world that was English.

Indeed, Clark recognized the ways in which landscapes connect to national identity, and that they can be perceived as being particular to a specific nationality. He had considered 
adapting M. R. James' 'Count Magnus' as a Ghost Story for Christmas, but decided that it would be too expensive as the story is set in Sweden and the BBC would not pay for filming there (Clark 2012). However, when the BBC did produce an adaptation of James' 'Number Thirteen' in 2006, which is set in Denmark, they simply moved the location of the story to England and avoided any problems with ill-fitting landscape, and Clark had himself already adapted the German-set The Treasure of Abbot Thomas. Therefore, while this article may emphasize the connections between landscape and nation, the importance of fidelity to the original narrative should not be overstated; what is more important is the way in which the adaptation engages with the viewer, and here it is the recognition of the landscape in the adaptation as being familiarly English that matters.

Despite Dempster's statement about British landscapes, the landscapes in these adaptations are particularly English ones, although as is so often the case, 'evocations of English landscape are often specifically regional, projecting a southern Englishness in the name of the whole' (Matless 2012: 17). Most commonly, they are the landscapes of East Anglia, with Norwich providing the locations for Barchester, and A Warning to the Curious being filmed in Norfolk, while A View from a Hill was recorded in 'a heavily autumnal Suffolk' (Dempster 2005: 6). What this particularly means is that these are the lands of invaders and colonizers, the Angles who drove out or intermarried with the previous inhabitants of the area. The connection to the local soil and landscape runs generations deep, but it has also been built upon the remains of earlier populations, with earlier connections to that landscape, overrun by the incomers. This emphasizes what could be considered as the silting up of history, with layer upon layer building on each other. An alternative image would be the one used in Stigma when Verity peels layer after layer off an onion, and yet there are always more layers waiting to be uncovered beneath. It is also Stigma that makes a connection further back even than the Angles by using the Neolithic landscape around 
Avebury as its setting. In other words, the landscape may encourage identification with the nation, but it also emphasizes how the landscape is interpreted through the history of human action upon it.

This concept of the layering of history emphasizes the continuity of human habitation and connection to landscape, while at the same time signalling that there is yet more to be uncovered. Again, the very idea of uncovering indicates that these things are hidden or 'occulted'. In A Warning to the Curious the narrative centres on the retention of the last of the three Crowns of East Anglia, which provide a supernatural protection from invasion for the country or at least for the region. The digging up of the Crown is what leads to the horrors of the story. Similarly, in Stigma it is the uncovering of the body beneath the apparently Neolithic stone that leads to the release of supernatural energy. It is thus the disturbance of the land, and the disturbance of the history that it contains, that leads to the horror; the nightmares of the past are literally uncovered.

A key aspect of the human relationship with the English landscape is that it does not represent a pristine wilderness at any point; even the most apparently wild area has been influenced by the actions of people. Macfarlane states that 'the human swallowing of the deep wood began around 4000BC, with the dawn of settled agriculture. During this Neolithic period, human intervention supplanted climatic change as the chief influence on the forest's nature' (2008: 96). However, the process of deforestation and turning the land to agriculture, and enclosure, and managed park, still took thousands of years, and is marked out by different patterns in the land.

But the landscape's connection to time does not only run into the past, but also into the future. Macfarlane describes a conversation with a friend that deals with this concept, emphasizing how the sublime conception of nature deals with its existence on a timescale 
outside that of human comprehension: 'Though we are now among the dominant species, she said, our age will pass, and our material legacy - unthinkable though it now is to imagine it vanished -will be absorbed by the land, becoming all but imperceptible' (2008: 283). The landscape may be changed by human activity, but ultimately the land will endure while the matter of the anthropocene ages; all that we as humans do will be absorbed back into nature. In other words, nature emphasizes the very fleetingness of not only the individual human existence but also the fleeting nature of the total duration of human presence on the planet. This clearly ties in to the Romantic concept of the Sublime in nature, which 'concentrated on the masses of rock, hill and lake to solicit from their wildness and immensity an answering violence, even extravagance, of feeling in the spectator' (Ousby 2002: 118). However, the sense of human insignificance in the face of the nature's endurance does not depend on the scale of landscape features that the Sublime focuses on, simply an awareness of the different timescales of the natural world as opposed to human activity within it.

Only one of the Ghost Story for Christmas productions really deals with this element, and that is Stigma. In this episode, a modern 1970s' family is brought into contact with the ancient practices of humans who laid a witch under a standing stone, while their radio broadcasts news of the Voyager space probe that is progressing out of the solar system and offering a last chance to look back at Earth. The past and the future are thus brought together by the narrative. This episode also makes use of the Neolithic human-altered landscape around Avebury, including the earthwork of Silbury Hill and the standing stones of Avebury. These human interventions in the landscape are presented as mysterious, as little understood, but also, with the burying of the witch beneath the stone, as an active human intervention to bind power, in this case the power of the witch, to the earth, as with the burying of the Crown of Anglia to protect the people of the land in A Warning to the Curious. However, the buried power here is female, that of the witch, connecting to Verity's growing power as a young 
woman superseding her mother, while the Crown of Anglia represents the male protective power of kings. Land here is shown as being able to contain the magical power of the witch, suppressing it until it is unleashed by the uncovering of her body, and once again serving to show how it is the uncovering, the revealing of the past that leads to horror. The land contains power, and so contains meaning, and part of this meaning comes from the changing of the landscape with the seasons.

\section{Broadcasting, landscape and season}

One of the ways in which we note the passing of the calendar year is with the changing of the landscape. Certain seasonal changes can be celebrated tourist attractions, whether that is the autumn of New England's woodlands, or the blossoming of cherry trees that can be tracked like a wave passing naturally over the islands of Japan through the months from March to May. The progress of this 'Sakura Zensen', or 'Cherry Blossom Front', is reported nightly on Japanese national news, complete with progress maps, demonstrating the way in which the media serves to connect people with the indicators of the changing seasons (Ferguson 2003: 5). On British television, the BBC's popular series Springwatch (2005-present), Autumnwatch (2006-present) and Winterwatch (2012-present) focus on the changes in wildlife across the calendar year, and give viewers the opportunity to observe not just the animals but also the wider changes in their environment as the seasons progress. Other productions also provide an ongoing look at the alterations in the rural landscape, and in rural life, throughout the year, such as Countryfile (2008-present), with its weekly coverage of current issues in human life in the countryside, which includes human interaction with animal and vegetable life and the land. Such programmes provide us with examples of what Helen Wheatley has termed 'spectacular landscape television' (2011), where looking at the 
landscape is both an object in itself and also a demonstration of the capabilities of television technology.

However, it is not just this spectacular landscape television that connects with the landscape. Andrew Higson outlined in 1987 the ways in which, in narrative film, landscape operates as a simple space in which the action happens, or as a physical place signifying realism through its actuality, or as a metaphor for character's emotional state, or as a spectacle in itself, and will most likely combine two or more of these characteristics (1987: 8). Such an understanding of the use of landscape can similarly be applied to narrative television. Drama frequently draws upon the display of landscape in a particular season in order to convey ideas of time, mood and identity. For example, Lark Rise to Candleford (2008-2011) drew upon idealized images of rural life in its golden-tinted nostalgic presentation of the end of the nineteenth century, dominated by views of consistently sunny countryside surrounding the cosy hamlet and village at the centre of the series. Such productions draw upon nostalgic concepts of the English pastoral landscape as a settled place of agriculture, small settlements and a slower way of life more in tune with the seasons. This represents a rural, primarily working- and middle-class version of the 'heritage' production as identified by Andrew Higson (2006), which presents the physical attractions of human structures such as great country houses resting in their carefully created parklands. Such visual pleasures are interpreted by Higson as presenting a politically conservative distraction from the social issues underlying both the represented historical society and the contemporary producing society. Wheatley also connects the history of 'spectacular landscape television' programmes and their representations of the landscape, particularly the way in which the landscapes are framed through the narratives imposed upon them, as one that presents 'the rather jingoistic ways in which the representation of landscape has been, and continues to be, tied to an image of national identity as simple and unchanging' (2011: 240). This concept fits 
with the wider use of 'heritage' as a means of emphasizing the surface appeal of a socially conservative past (see, e.g. Higson 20062006; Wright 2009; Hewison 1987), although it has been pointed out by, among others, Raphael Samuel in his Theatres of Memory that engagement with heritage does not have to be upper- or middle-class and conservative and that many heritage movements have been involved with widening access to history and its locations (2012).

Apart from her work on landscape, Helen Wheatley's consideration of Gothic television presented the concept of 'dark' or 'feel bad heritage' programming, which shares characteristics with the conservative heritage production, but uses them to disrupt and disturb (2006: 49). Making particular reference to the Ghost Story for Christmas, Wheatley argues that such programming 'refuses the sanitation of nostalgia' in order to 'offer the viewer narratives of fear and anxiety set in a past which is not only marked by a sense of decay or dilapidation, but which is also disturbed by uncanny happenings and supernatural events' (2006: 50). In particular, 'the Gothic literary adaptation removes the surety of the past as a haven or site of nostalgia' (Wheatley 2006: 50). In other words, 'dark heritage' programming may share heritage programming's use of detailed historical settings and a fascination with depicting the surfaces of those settings, but presents these surfaces as distracting, concealing the rottenness and darkness beneath. In these productions, the past is not neat, elegant and organized, but chaotic, grimy and brutal, although often still with an attractive surface.

Peter Hutchings has discussed a similar concept of the disruption of the heritage perspective through the idea of the 'uncanny landscape' (2004). Here, the landscape is 'suffused with a sense of profound and sometimes apocalyptic anxiety; it is also a landscape of a comprehensive dispossession and vacancy' (2004: 29). It is a place where human activity is displaced, ultimately unimportant, where even the thousands of years of human alteration of the landscape make way to more ancient powers. In this landscape, Hutchings argues, the
Commented [K1]: The publication year of Higson (2003) has been changed to match the publication year (2006) given in the reference list. Please confirm whether this is correct. 
heritage drama's identification of landscape with national identity is not only questioned, but it can disappear as 'this is not a landscape where we find ourselves as modern national subjects; it is instead a landscape where that sense of identity is diminished or removed entirely' with the representation of human individual or social agency as ultimately powerless (2004: 29).

The Ghost Story for Christmas draws upon both the heritage and the 'dark heritage' or 'uncanny landscape' approaches to the English countryside in order to generate a sense of unease. This is part of a particular concept of Englishness that is tied closely in with the work of M. R. James. Indeed, Michael Chabon has called James 'about as English as it is possible for an English author to be' because of his skill at the English Christmas tradition of 'sit[ting] by a crackling yule fire and [scaring] one's friends out of their wits. (And it would be hard to imagine anything more English than that)' (2010: 111). This English tradition is thus one of accepting the comfort in which one currently exists and pointing out that it is surrounded by potential horrors.

In particular, this can be seen to emphasize the temporary nature of any specific way of life and the way in which any perceived current stability only conceals long-standing, underlying dangers and powers. Roy Strong has claimed that Hardy's depiction of the landscape in The Return of the Native "catches something fundamental in the English perception of their countryside: the primeval timelessness of the landscape' (2012: 156), which Hardy described as giving 'ballast to the mind adrift on change, and harassed by the irrepressible New' (1978: 56). The 'dark heritage' version of this feeling is the sublime sensation that the rural landscape is not a reassuring indicator of permanence, nor a comforting example of man's dominance over nature in the form of agriculture and planned parkland, but rather a symbol of the thin skin of civilization that covers the deep and ancient horrors of the world. 
The role that season plays in these productions is twofold. First, as Christmas ghost stories they tie in to a particular English narrative tradition of seasonal tales of horror (see Johnston 2015). More importantly for this article, though, is the way in which a depicted landscape communicates a sense of the season and the effects of the season on the characters, and thus how it affects the audience. These depictions of landscape go beyond being merely simple spaces in which the action takes place, nor are they used as spectacles in themselves, instead acting both as metaphors of emotional state and to ground the fantastic narratives in realism through their physical existence as actual spaces.

In his exploration of the ritual year in Britain, Ronald Hutton argues that:

The rhythms of the British year are timeless, and impose certain perpetual patterns upon calendar customs: a yearning for light, greenery, warmth, and joy in midwinter, a propensity to celebrate the spring with symbols of rebirth, an impulse to make merry in the sunlight and open air during the summer, and a tendency for thoughts to turn towards death and the uncanny at the onset of winter. (2001: 426)

This explains both the emotional response to these narratives at Christmas time and the responses to the depicted seasons within the productions. These narratives typically take place in the late summer or early autumn. At this point in the year, there is still sufficient vegetation to provide a concealing thicket, and the shading of leaves that makes a woodland appear dark compared to the brightness of day outside. However, there is also an indication of death and decay as the vegetation starts to turn towards autumn. The season itself is liminal, and this presence on the borderline is shown by the landscape, providing the viewer 
with further uneasy hints about the nature of the narrative and characters, on the borderlines between life and death.

This is, of course, partly a purely practical matter of when the production has to be made in order to be ready for Christmas broadcast. However, the Ghost Story for Christmas exploits this practical issue to present a countryside that can be appealing, sunlit and heritagedrama beautiful, but that can also be threatening, cold and harsh. Only one episode, The Ice House, has a summer setting, with characters in shirtsleeves enjoying the sunny garden of a country house spa, but this serves to emphasize the uncanny coldness that is a central part of the narrative. In other narratives, characters seem affected appropriately by the weather, their wrapping up in warm clothes appreciated rather than overheating them, a problem encountered by the typical demands of filming a Christmas episode in August or September. The performance of the actors is thus affected by the physical nature of the season in which the recording is made, and so conveys further impressions of warmth and cold to the audience. As cold is frequently due to being exposed to the elements, it also provides a sense of being exposed to the other dangers of the environment, natural or supernatural.

\section{Conclusion}

We can understand the Ghost Story for Christmas as fitting with the 'dark heritage' strand of programming identified by Wheatley, which utilizes the captivating detail of the represented past not to distract so much as to emphasize the horrific aspects of history. While Wheatley used the Ghost Story for Christmas as a key example of this type of programme, she did not focus on its use of landscape and its engagement with the seasons. This use draws upon historical associations of particular landscapes, particularly those of the southeast and east of England, with notions of English identity, which is then regularly presented as an overall 
British identity. What the Ghost Story for Christmas does is to show this identity to be mutable, that the polite, restrained, modern society that its protagonists inhabit is built on a horrific past that the land both conceals but also yields up to the over-curious. In doing so, and in the lack of any active participation in or apparent reaction to the horrific events that occur within it, the landscape demonstrates its detachment from petty human concerns. In this way, these landscapes, which viewers such as Dempster consider to be archetypally British, a part of the national identity, are revealed to be nothing of the sort. They are, instead, simply the landscape onto which human ideas and perceptions have overlaid this notion of nations and identity, but that not only predates them but will also outlast those notions, and even humanity itself. The protagonist of a Ghost Story for Christmas may shiver at the cold, or start at the apparent motion glimpsed through trees and undergrowth, but the real horror is that the environment reveals all of these events to be, ultimately, inconsequential.

\section{References}

Billig, P. M. (1995), Banal Nationalism, Thousand Oaks, CA: Sage Publications.

Chabon, M. (2010), 'The Oether James', in Maps and Legends: Reading and Writing Along the Borderlands, London: Fourth Estate, pp. 109-20.

Clark, L. G. (2012), 'Introduction to Stigma', The M. R. James Collection, DVD extra, London: BFI.

Dempster, S. (2005), 'Ghosts in the Machine', The Guardian, 17 December, pp. 4-6. 
Ferguson, W. (2003), Hokkaido Highway Blues: Hitchhiking Japan, Edinburgh: Canongate Books Ltd.

Hardy, T. (1978), The Return of the Native (ed. G. Woodcock), Harmondsworth: Penguin Classics.

Hayman, R. (2003), Trees: Woodland and Western Civilization, London: Hambledon Continuum.

Hewison, R. (1987), The Heritage Industry: Britain in a Climate of Decline, London: Methuen.

Higson, A. (1987), ‘The landscapes of television', Landscape Research, 12:3, pp. 8-13.

(2006), 'Re-presenting the national past: Nostalgia and pastiche in the heritage film', in

L. D. Friedman (ed.), Fires were Started: British Cinema and Thatcherism, London:

Wallflower, pp. 91-109. 
Hutchings, P. (2004), 'Uncanny landscapes in British Film and Television', Visual Culture in Britain, 5:2, pp. 27-40.

Hutton, R. (2001), Stations of the Sun: A History of the Ritual Year in Britain, Oxford: Oxford University Press.

James, M. R. (2006), The Haunted Dolls' House and Other Ghost Stories (ed. S. T. Joshi), London: Penguin.

Johnston, D. (2015), Haunted Seasons: Television Ghost Stories for Christmas and Horror for Halloween, Basingstoke: Palgrave Macmillan.

Lowenthal, D. (1991), 'British national identity and the English landscape', Rural History, $2: 2$, pp. $205-30$.

Macfarlane, R. (2008), The Wild Places, London: Granta Books.

Matless, D. (2012), Landscape and Englishness, London: Reaktion Books.

Ousby, I. (2002), The Englishman's England: Taste, Travel and the Rise of Tourism, London: Pimlico. 
Roberts, L. (2016), 'Landscapes in the frame: Exploring the hinterlands of the British procedural drama', New Review of Film and Television Studies, 14:3, pp. 364-85.

Samuel, R. (2012), Theatres of Memory: Past and Present in Contemporary Culture, London: Verso Books.

Strong, R. (2012), Visions of England: Or Why We Still Dream of a Place in the Country, London: Vintage Books.

Thompson, T. W. (2004), “I Shall Most Likely be Out on the Links": Golf as metaphor in the ghost stories of M. R. James', Papers on Language and Literature, 40:4, pp. 339-52.

Wheatley, H. (2006), Gothic Television, Manchester: Manchester University Press.

(2011), 'Beautiful images in spectacular clarity: Spectacular television, landscape programming and the question of (tele)visual pleasure', Screen, 52:2, pp. 233-48.

Wright, P. (2009), On Living in an Old Country: The National Past in Contemporary Britain, Oxford: Oxford University Press. 


\section{Television programmes}

Autumnwatch (2006-present, UK: BBC).

Countryfile (2008-present, UK: BBC).

Ghost Story for Christmas (1971-1978, 2005-2006, 2015, UK: BBC).

'A View from a Hill' (2005), Luke Watson (dir.), Ghost Story for Christmas (르 December, UK: BBC).

‘A Warning to the Curious' (1972), Lawrence Gordon Clarke (dir.), Ghost Story for Christmas (24 December, UK: BBC).

'The Ash Tree' (1975), Lawrence Gordon Clarke (dir.), Ghost Story for Christmas (23 December, UK: BBC).

'The Ice House' (1978), Derek Lister (dir.), Ghost Story for Christmas (25 December, $\mathrm{UK}: \mathrm{BBC})$.

'Lost Hearts' (1973), Lawrence Gordon Clarke (dir.), Ghost Story for Christmas (25 December, UK: BBC).

'Number 13' (2006), Pier Wilkie (dir.) Ghost Story for Christmas (22 December, UK: $\mathrm{BBC})$.

'The Signalman' (1976), Lawrence Gordon Clarke (dir.), Ghost Story for Christmas (22 December, UK: BBC).

'The Stalls of Barchester' (1971), Lawrence Gordon Clarke (dir.), Ghost Story for Christmas (24 December, UK: BBC).

'Stigma' (1977), Lawrence Gordon Clarke (dir.), Ghost Story for Christmas (28 December, UK: BBC). 
The Tractate Middoth' (2013), Mark Gatiss (dir.), Ghost Story for Christmas (25 December, UK: BBC).

'The Treasure of Abbot Thomas' (1974), Lawrence Gordon Clarke (dir.), Ghost Story for Christmas (23 December, UK: BBC).

Lark Rise to Candleford (2008-2011, UK: BBC).

Springwatch (2005-present, UK: BBC).

Winterwatch (2012-present, UK: BBC).

\section{Contributor details}

Derek Johnston is llecturer in broadcast literaey at Queen's University, Belfast, and the author of Haunted Seasons: Television Ghost Stories for Christmas and Horror for Halloween (Palgrave, 2015). His research is primarily concerned with 'escapist' genres, such as horror, science fiction and historical drama, and particularly their history within British media contexts. He has contributed chapters and articles to a range of journals and edited collections, including Critical Studies in Television, Networking Knowledge, Science Fiction Film and Television, The Routledge Companion to Science Fiction, The Liverpool Companion to World Science Fiction Film and The Routledge Companion to the Ghost Story.

\section{Contact:}

Queen's University Belfast, University Road, Belfast, BT7 1NN, UK.

E-mail: derek.johnston@qub.ac.uk. 